\title{
Effects and mechanisms of cavidine protecting mice against
}

\section{LPS-induced endotoxic shock}

Weifeng Li, Hailin Zhang, Xiaofeng Niu*, Xiumei Wang, Yu Wang, Zehong He, Huan Yao

School of Pharmacy, Xi'an Jiaotong University, Xi'an 710061, P.R. China.

E-Mail: liwf@mail.xjtu.edu.cn

*Corresponding author. Xiaofeng Niu, School of Pharmacy, Xi'an Jiaotong University,

76" Western Yanta Road, Xi'an, Shaanxi 710061, P.R. China. Tel.: +86 2982655139.

E-mail: niuxf@mail.xjtu.edu.cn 


\section{Abstract}

LPS sensitized mice are usually considered as an experimental model of endotoxin shock. The present study aims to evaluate effects of cavidine on LPS-induced endotoxin shock. Mice were intraperitoneally administrated with cavidine (1, 3 and 10 $\mathrm{mg} / \mathrm{kg})$ or DEX $(5 \mathrm{mg} / \mathrm{kg})$ at 1 and $12 \mathrm{~h}$ before injecting LPS (30 mg/kg) intraperitoneally. Blood samples, liver, lung and kidney tissues were harvested after LPS injection. The study demonstrated that pretreatment with cavidine reduced the mortality of mice during $72 \mathrm{~h}$ after endotoxin injection. In addition, cavidine administration significantly attenuated histological pathophysiology features of LPS-induced injury in lung, liver and kidney. Furthermore, cavidine administration inhibited endotoxin-induced production of pro-inflammatory cytokines including TNF- $\alpha$, IL-6 and HMGB1. Moreover, cavidine pretreatment attenuated the phosphorylation of mitogen-activated protein kinase primed by LPS. In summary, cavidine protects mice against LPS-induced endotoxic shock via inhibiting early pro-inflammatory cytokine TNF- $\alpha$, IL-6 and late-phase cytokine HMGB1, and the modulation of HMGB1 may be related with MAPK signal pathway.

Key word: Cavidine; Endotoxic shock; TNF- $\alpha$; IL-6; HMGB1 


\section{Introduction}

Endotoxic shock was caused by a disordered immune response to an infection and characterized clinically by systemic hypotension, hyporeactiveness to vasoconstrictors and organ dysfunction (Nduka and Parrillo, 2009; Stearns-Kurosawa et al., 2011). The development of this severe syndrome was mostly caused by lipopolysaccharide (LPS), a constituent of the Gram-negative bacteria cell wall (Liu et al., 2008). When being administered to animals or cells, LPS exerts its profound effects on the host by activating LPS sensitive pro-inflammatory cells, such as monocytes and endothelial cells, to release various cytokines, lipid mediators and free radicals (Qi et al., 2013).

In macrophages, LPS induces the transcription of mitogen-activated protein kinases (MAPKs) which play an essential role in the initiation and development of endotoxic shock (Roux and Blenis, 2004). MAPKs include three pathways, the extracellular signal-regulated protein kinases 1 and 2 (ERK1/2), and two stress-activated protein kinases designated as p38 and c-Jun N-terminal kinase (Johnson et al., 2005). Once activated by kinases, MAPK can phosphorylate the transcription factors or downstream kinases that lead to the expression of pro-inflammatory mediators (Alves et al., 2013).

Endotoxic shock, a potentially fatal clinical syndrome, is mediated by an early mediator including tumor necrosis factor (TNF)- $\alpha$, interleukin (IL)-1, IL-6, interferon-gamma (INF- $\gamma$ ), nitric oxide (NO) and late-phase mediator high mobility group box 1 (HMGB1) (Li et al., 2010; Liu et al., 2015). Although the overproduction of LPS-induced TNF- $\alpha$ and IL-6 participate in inflammatory tissue injuries and lethal 
shock, drugs anti-TNF- $\alpha$ and anti-IL-6 haven't significantly improved the survival rate in endotoxic shock ( Kumar and Sharma, 2010). It in part because peak mediator activity often has passed before therapy, thus late-acting downstream effectors that mediate endotoxic shock lethality such as HMGB1 may be more relevant to the therapeutic target.

HMGB1 protein, releasing at $8 \mathrm{~h}$ after endotoxin exposure, plays an important role in pathogenesis of sepsis as an important late-phase mediator (Czura and Tracey, 2003). HMGB1 is a non-histone nuclear protein originally identified as an important factor in the regulation of genetic information by facilitating the binding of transcription factors to their cognate DNA sequences. The cytokine activity of HMGB1 has been well documented in many cell types, including macrophages/monocytes endothelium and neutrophil. Resting, non-activated inflammatory cells such as monocytes or macrophages contain HMGB1 in the nuclear compartment (Feng et al., 2008). When being activated by LPS or inflammatory cytokines, cells translocate the nuclear HMGB1 into cytoplasm, and then HMGB1 is exocytosed. Triggered HMGB1 can lead to a cascade of inflammatory responses such as tissue damage and even death through multiple pathways including macrophage activation and release of pro-inflammatory cytokines (Sun and Chao, 2005).

Corydalis impatiens was widely used for treatment of skin injuries, hepatitis, cholecystitis and scabies as a traditional Tibetan herb. Cavidine (Fig. 1) isolated from Corydalis impatiens that has biological and pharmacological activity of anti-inflammatory, (Niu et al., 2013). Previously, we found that cavidine inhibits the 
expression of pro-inflammatory cytokines in cultured cells and experimental inflammatory animal models as a potent inhibitor of COX-2 (Niu et al., 2015). The present study aims to investigate the pharmacological effect of cavidine on Gram-negative bacteria caused endotoxic shock experimental animal models and elucidate mechanism through studying LPS-induced murine primary peritoneal macrophages' responses to cavidine.

\section{Materials and methods}

\subsection{Drugs}

Cavidine was isolated from Corydalis impatiens as previously described (Niu et al., 2013). Dexamethasone (DEX) was supplied by Xi'an Lijun Pharmaceutical Company Limited (Xi'an, China). Lipopolysaccharide (LPS, E coli), SB203580 and PD98059 was purchased from Sigma (St. Louis, MO, USA). RPMI-1640 was purchased from Gibco (Gibco-BRL, Gaithersburg, MD, USA). Sodium thioglycolate was purchased from Sinopharm Chemical Reagent Co., Ltd. (Shanghai, China). The enzyme immunosorbent assay (ELISA) kits for mouse TNF- $\alpha$, IL-6 and HMGB1 were purchased from R\&D Systems (Minneapolis, MN, USA). Polyclonal antibodies against HMGB1, ERK1/2 and p38 were purchased from R\&D Systems (Minneapolis, MN, USA). Anti-glyceraldehyde-3-phosphate dehydrogenase (GAPDH) antibody was purchased from Santa Cruz Biotechnology, Inc. (Santa Cruz, CA, USA). Polyvinylidene fiuoride (PVDF) membranes were purchased from Pall Gelman Laboratory (Ann Arbor, MI, USA). Other reagents were of commercially available 
analytical grade.

\subsection{Animals}

Mice were obtained from the Experimental Animal Center of Xi'an Jiaotong University. The mice were housed under controlled temperature and humidity with water and food adlibitum. The experimental procedures was approved by the Ethical Committee of Xi'an Jiaotong University, and conformed to the Guide for the Care and Use of Laboratory Animals published by the US National Institutes of Health (NIH Publication No. 85-23, revised 1996).

\subsection{Induction of endotoxic shock and drug treatment}

Male mice were randomly divided into 6 groups, each consisting of 12 animals: (A) normal control group, in which the mice were administrated the vehicle; (B) LPS group, in which the mice were intraperitoneally injected LPS $(30 \mathrm{mg} / \mathrm{kg}) ;(\mathrm{C}, \mathrm{D}, \mathrm{E})$ cavidine (1, 3 and $10 \mathrm{mg} / \mathrm{kg})+$ LPS groups, in which the mice were administrated cavidine at various doses $(1,3$ and $10 \mathrm{mg} / \mathrm{kg}$ i.p) then were intraperitoneally injected LPS, respectively; (F) DEX + LPS group, in which the mice were administrated DEX ( $5 \mathrm{mg} / \mathrm{kg}$ i.p) then were intraperitoneally injected LPS. Cavidine $(1,3$ and $10 \mathrm{mg} / \mathrm{kg})$ groups and DEX group were administered twice $12 \mathrm{~h}$ apart. One hour after the second dose of cavidine or DEX, all mice (excepted for the normal control group) were intraperitoneally injected with $30 \mathrm{mg} / \mathrm{kg}$ LPS (dissolved in saline) to induce endotoxin shock. After the injection of LPS, mice were monitored for the clinical manifestations 
of endotoxic shock and mortality for $72 \mathrm{~h}$. Blood samples from mice were taken from the right ventricle orbital veniplex using a heparinized syringe with a needle. Liver, lung and kidney were harvested then kept in $4 \%$ formalin for macroscopic scoring, histopathological examination and the remaining portion was stored at $-80^{\circ} \mathrm{C}$ for biochemical study.

\subsection{Determination of TNF- $\alpha$, IL-6 and HMGB 1}

Blood sample harvested from mice was centrifuged at $1800 \times \mathrm{g}$ for $10 \mathrm{~min}$, and the supernatant was collected. Lung, liver and kidney tissues were weighed (100 mg), then homogenized in $0.6 \mathrm{~mL}$ of ice-cold RIPA lysis buffer containing $1 \%$ protease inhibitor cocktail and 1\% phosphatase inhibitor cocktail, respectively. The lysate was centrifuged $\left(16,000 \times \mathrm{g}, 4^{\circ} \mathrm{C}\right)$ for $10 \mathrm{~min}$, and the supernatant was harvested. Level of TNF- $\alpha$, IL-6 and HMGB1 in serum and tissue was measured by a ELISA kits. All samples were assayed in duplicate, and equivocal results were repeated. The cytokine concentration was calculated from a standard curve prepared with corresponding recombinant mouse cytokine.

\subsection{Histopathological examination}

Lung, liver and kidney collected from mice were fixed in Bouin fluid for $48 \mathrm{~h}$, dehydrated with increasing concentrations of ethanol, embedded in paraffin then cut into $5 \mu \mathrm{m}$ sections. The paraffin sections were deparafinized, hydrated and stained with hematoxylin and eosin $(\mathrm{H} \& \mathrm{E})$ to determine the degree of damage induced by 
endotoxic shock. Pathological changes were evaluated under a light microscope.

\subsection{Immunohistochemical study}

To assess HMGB1 expression in the tissues, immunohistochemical staining was performed. Sections were deparaffinized and rehydrated with xylene and graded ethanol solution. Next, sections were incubated with $3.0 \%$ hydrogen peroxide in methanol for $10 \mathrm{~min}$ at $37^{\circ} \mathrm{C}$ to quench the activity of endogenous peroxidase. Then, slides were incubated with polyclonal antibody of HMGB1 (diluted to 1:500) for $16 \mathrm{~h}$ at $4{ }^{\circ} \mathrm{C}$ and the biotinylated polyclonal rabbit antimouse secondary antibody for 30 min at $37^{\circ} \mathrm{C}$. After washing with phosphate-buffered saline, sections were stained with 3, 3'-diaminobenzidine until the brown reaction product could be visualized. Then sections were dehydrated with increasing concentration of ethanol again. At last, sections were mounted with neutral gum. All tissue sections were examined in an Olympus DP-71 microscope. Results were evaluated semi-quantitatively according to the percentage of positive cells in ten random selected fields under 100-fold magnification.

\subsection{Western Blotting}

Lung, liver and kidney tissues harvested were homogenized and centrifuged $\left(16,000 \times g, 4^{\circ} \mathrm{C}\right)$ for $15 \mathrm{~min}$, and then supernatants were harvested for the Western blotting analyses. Protein concentrations in all samples were quantified using the bicinchoninic acid method. Every sample was treated with bromophenol blue and 
dithiothreitol (DTT, final concentration $=10 \mathrm{mM}$ ) before to electrophoresis. For Western blotting, about $30 \mu$ protein from each sample was separated on $10 \%$ sodium dodecylsulfate-polyacrylamide gel (SDS-PAGE) using electrophoresis. Protein separated was transferred onto PVDF membrane by wet blotting. Membrane was blocked with 5\% skim milk in TBST buffer (20 mM Tris, $500 \mathrm{mM} \mathrm{NaCl,} \mathrm{pH} 7.5$ and $0.1 \%$ Tween20) for $2 \mathrm{~h}$ at room temperature and then incubated with primary antibodies against GAPDH (diluted 1:1000 dilutions), HMGB1, p38 and ERK1/2 (diluted1:1000 in TBST) overnight at $4^{\circ} \mathrm{C}$. The membranes were washed three times using TBST then were incubated with anti-rabbit horseradish peroxidase-conjugated antibody (diluted 1:15000 in TBST) for $1 \mathrm{~h}$ at room temperature. Immunoreactive protein was measured using an enhanced chemiluminescence system. All Western blotting studies were repeated three times.

\subsection{Cell culture}

Macrophages were harvested from peritoneal exudates in 60 female Kunming mice (20-25 g) after 7 days intraperitoneal injection with $1.0 \mathrm{~mL} 1 \%$ sodium thioglycolate. The peritoneal cavity of mice was lavaged with $5 \mathrm{~mL}$ of phosphate buffered saline (mM: $\mathrm{NaCl} 137, \mathrm{KCl} 2.7, \mathrm{KH}_{2} \mathrm{PO}_{4}$ 1.5, $\mathrm{NaHPO}_{4}$ 8.1, $\mathrm{pH}$ 7.4). Fluid sucked out from peritoneal were centrifuged at $800 \times g$ for $5 \mathrm{~min}$ and washed three times by phosphate buffered saline. Cells obtained were suspended in RPMI-1640 supplemented with $10 \%$ fetal bovine serum then cultured in the incubator with $95 \%$ air, $5 \% \mathrm{CO}_{2}$ at $37^{\circ} \mathrm{C}$. 


\subsection{Drug treatment and LPS challenge}

Peritoneal macrophages $\left(1 \times 10^{6}\right.$ cells $\left./ \mathrm{mL}\right)$ were treated with cavidine $\left(10^{-3}, 10^{-2}\right.$ and $\left.10^{-1} \mathrm{mg} / \mathrm{mL}\right)$, p38 MAPK inhibitor SB203580 $(10 \mu \mathrm{M})$ or ERK1/2 inhibitor PD98059 $(20 \mu \mathrm{M})$ for $24 \mathrm{~h}$, and then stimulated with LPS $(10 \mu \mathrm{g} / \mathrm{mL})$ for $16 \mathrm{~h}$. Next, cells were washed three times with cold PBS, then lysed in ice-cold lysis buffer (50 mM Tris-HCl, $\mathrm{pH}$ 7.5; 150 mM NaCl; 1 mM EDTA; 20 mM NaF; 0.5\% NP-40; and

$1 \%$ Triton $\mathrm{X}-100)$ containing a protease inhibitor and phosphatase inhibitor cocktail for $40 \mathrm{~min}$. The media in the plate was centrifuged at $16,000 \times g$ for $10 \min 4^{\circ} \mathrm{C}$. Supernatant was harvested for HMGB1 and MAPK analysis using ELISA and Western blotting.

\subsection{Statistical Analysis}

All dates were presented as mean \pm SE. Statistical analysis was carried out using the GraphPad Prism 5.01 (California, USA). All statistical tests were performed using one-way analysis of variance (ANOVA) followed by the Student-Newman-Keuls test. $P<0.05$ was considered as the accepted level of significance for the test.

\section{Results}

3.1. Effects of cavidine on the survival rate of mice after LPS-shock

Mice were observed for three days after establishment of endotoxic shock model. Results showed that mice from LPS-treatment developed typical signs of diarrhea, 
hypergasia and died. Stimulation with LPS in mice even resulted in a high mortality rate $(66.7 \%)$ and the blood was sticky and only small quantities could be drawn. As Fig. 2 shown, both treatment with cavidine and DEX groups reduced mortality when compared that with LPS group. The mortality were reduced to $58.3 \%, 41.7 \%$ and $16.7 \%$ $(P<0.05)$ respectively, when mice was pretreatment with cavidine $(1,3,10 \mathrm{mg} / \mathrm{kg})$. The three exploratory doses of cavidine showed improved survival rates following LPS-induced endotoxic shock in mice.

\subsection{Effects of cavidine on LPS-induced TNF- $\alpha$, IL-6 and HMGB1 levels in serum} The inhibitory effects of cavidine on TNF- $\alpha$, IL-6 and HMGB1 levels in serum was analyzed using ELISA. As early media, TNF- $\alpha$ and IL-6 was released to serum as LPS induced. The result in Fig. 3A and B suggested that induced with LPS significantly increased the levels of TNF- $\alpha$ and IL-6 at each time point when compared with that of control group. Treatment with cavidine significantly decreased the activity of TNF- $\alpha$ and IL- 6 in serum obtained from mice at different time after LPS induced. In addition, results showed that levels of TNF- $\alpha$ and IL-6 reached the maximum at $6 \mathrm{~h}$ after LPS stimulation. With the stimulated time increased, TNF- $\alpha$ and IL-6 release was reduced. Results in Fig. 3C indicated that levels of HMGB1 has no significant difference between the groups during $6 \mathrm{~h}$ LPS induced. At $12 \mathrm{~h}$ after LPS induced, levels of HMGB1 in serum reached a maximum. At late-phase of endotoxic shock, LPS-induction significantly increased levels of HMGB1 in serum, but cavidine pretreatment attenuated HMGB1 expression. 
3.3. Effects of cavidine on TNF- $\alpha$ and IL-6 production in LPS-induced mouse tissue

After LPS injection, levels of TNF- $\alpha$ and IL-6 in serum elevated dramatically and reached a maximum at about $6 \mathrm{~h}$ and then declined gradually. Thus, lung, liver and kidney tissues were obtained at $6 \mathrm{~h}$ after LPS stimulation to study. As shown in Fig. 4A and B, levels of TNF- $\alpha$ and IL- 6 were notably elevated in lung, liver and kidney tissues when compared with the control group. Cavidine $(1,3$, and $10 \mathrm{mg} / \mathrm{kg})$ and DEX (5 mg/kg) efficiently reduced TNF- $\alpha$ and IL-6 levels in tissue sections from lung, liver and kidney.

3.4. Effects of cavidine on HMGB1 expression in LPS-induced mouse tissue

After LPS injection, HMGB1 elevated dramatically and reached a maximum at 12 $\mathrm{h}$, which was different with TNF- $\alpha$ and IL-6. Therefore, lung, liver and kidney tissue obtained at $12 \mathrm{~h}$ after LPS stimulation were chosen to study. As shown in Fig. 4C, the levels of HMGB1 were notably increased in lung, liver and kidney tissue as LPS induction, while pretreatment with cavidine and DEX attenuated HMGB1 levels.

\subsection{Effects of cavidine on histopathological evaluation}

Six hours after LPS treatment, tissue sections from the lung, liver and kidney were prepared for histopathological analysis by H\&E staining. Compared with LPS group, pretreatment with cavidine attenuated congestion, hemorrhage and leukocyte infiltration in the lung tissue (Fig. 5). Liver tissue sections showed wide-ranging 
laminated necrosis and leukocyte infiltration into the parenchyma in the LPS group (Fig. 6). Tubular hepatic cell swelling and hemorrhage was observed in kidney in LPS group (Fig. 7). Pretreatment with cavidine remarkably attenuated the extent and severity of inflammation injury in liver and kidney. These results suggested that administration of cavidine improved the pathological changes and injury in lung, liver and kidney tissues induced by LPS.

3.6. Effects of cavidine on immunohistochemistry evaluation

HMGB1 protein expression was evaluated by immunohistochemistry to investigate the effect of cavidine. As Fig. 8 shown, there was few specific expression of HMGB1 in control tissue(A). Protein expression of HMGB1 was significantly increased in the tissue of model animals (B); administration with cavidine (1, 3, 10 $\mathrm{mg} / \mathrm{kg}$ ) protein expression of HMGB1 was effectively inhibited in all tissue( C, D, E); treatment of DEX (5 mg/kg), HMGB1 expression was obviously reduced(F). Specific expression of HMGB1 was very weak in the tissue of high-dose group. Compared with LPS group, pretreatment with cavidine notably reduced the protein expression of HMGB1. Results indicated that cavidine protects mice against LPS-induced endotoxic shock possibly by inhibiting the HMGB1 protein expression in the tissues. The results were the semiquantitative analysis of HMGB1 expression.

\subsection{Effects of cavidine on MAPK pathway expression}

The phosphorylation and activation status of kinases in the MAPK system include 
ERK1/2, JNK and p38, which play essential roles in the regulation of proinflammatory cytokine production. To determine whether cavidine mediates the expression of HMGB1 and MAPK pathway, the activation states of HMGB1, P38 and ERK1/2 MAPKs were examined by Western blotting. As result in Fig. 9 and Fig. 10 shown, stimulation with LPS caused increased level of HMGB1, P38 and ERK1/2 protein expression in lung, liver and kidney tissues compared with control group ( $p<$ 0.01). Pretreatment with cavidine significantly suppressed HMGB1protein expression according with the phosphorylation of ERK1/2 and p38 MAPK. These results showed that cavidine blocked expression of HMGB1 and MAPK signal transduction in LPS-induced endotoxic shock mice.

\subsection{Effects of cavidine on HMGB1 expression in LPS-induced macrophages}

To elucidate mechanism of cavidine' inhibitory effect on LPS-induced HMGB1 in endotoxic shock mice, LPS-induced response in murine primary peritoneal macrophages was investigated. The effects of cavidine on the production of HMGB1 was analyzed using ELISA. The result of ELISA suggested that incubated with 10 $\mu \mathrm{g} / \mathrm{mL}$ LPS can significantly stimulate the expression of HMGB1 $(P<0.01)$. While pretreatment with cavidine, SB203580 or PD98059 have a marked decrease in the HMGB1 production. As Fig. 11 shown, treatment with cavidine $\left(1 \times 10^{-3}, 1 \times 10^{-2}\right.$, $10^{-1} \mathrm{mg} / \mathrm{mL}$ ) had $5.65 \%, 40.11 \%, 64.97 \%$ inhibition rate. Pretreatment with the specific p38 MAPK inhibitor SB203580 and ERK1/2 inhibitor PD98059 had $63.13 \%$ and $50.87 \%$ inhibition rate, respectively. 
3.9. Effects of cavidine on MAPK pathway in LPS-induced macrophages

MAP kinases play a critical role in the control of cellular responses. To understand the mechanism by which cavidine inhibits LPS induced HMGB1, the effect of cavidine on the activation of p38 and ERK-1/2 in LPS-stimulated macrophages (Fig. 12) were investigated. Results showed that phosphorylation of p38 and ERK-1/2 was markedly induced by stimulation with LPS, whereas pretreatment of the cells with cavidine, SB203580 or PD98059 obviously inhibited HMGB1, p38 and ERK-1/2 MAP kinase activation compared to LPS groups. These results suggested that the release of HMGB1 was related to the activation MAPK and cavidnie reduced LPS-induced expression of HMGB1 through blocking p38 and ERK-1/2 MAP kinase pathways.

\section{Discussion}

Endotoxic shock is a syndrome characterized by systemic inflammatory response to infection (Li et al., 2014). LPS challenge results in pathophysiologic changes and death, which is usually considered as an experimental model of endotoxin shock to evaluate the anti-inflammatory effect of test drugs (Freudenberg and Galanos, 1990 ). Injection of $30 \mathrm{mg} / \mathrm{kg}$ LPS into mice results in $66.7 \%$ lethality and toxemia-like symptoms, such as piloerection, hypothermia, shivering, tachycardia and lethargy. In addition, exposure to a high dose of LPS causes an acute inflammatory response in mice, which evokes a state characterized by multi-organ system failure such as lung, 
liver, kidney injury and cell death (Szarka et al., 1997; Hsu et al., 2006). In present study, cavidine reduced mice mortality and mitigates some toxemia-like symptoms. In addition, cavidine reduced hemorrhage, necrosis and infiltration of inflammatory cells in tissues of lung, liver and kidney following LPS-induced endotoxic shock. These results suggest that cavidine is a potential drug to be used for endotoxic shock therapy.

In present study, we measured TNF- $\alpha$ and IL- 6 levels in plasma and tissues from endotoxic shock mice. As results shown, serum TNF- $\alpha$ and IL-6 levels rose dramatically at $6 \mathrm{~h}$ after LPS injection, while cavidine pretreatment significantly decreased the levels of TNF- $\alpha$ and IL-6 in endotoxic shock mice. Cytokines have been implicated as important factors in the pathophysiology of endotoxic shock and the development of cardiovascular dysfunction in endotoxemia (Damas et al., 1989; Kuhns et al., 1995). Bacterial LPS in the bloodstream induces large amounts of inflammatory cytokines such as TNF- $\alpha$, IL-6 and HMGB1, which are thought to contribute to the LPS-induced symptoms of endotoxic shock and mortality (Dinarello, 1997; Takano et al., 1997). TNF- $\alpha$ is the cardinal inflammatory mediator associated with various inflammatory diseases (Dinarello, 2000). As LPS challenge, TNF- $\alpha$ is released at the first, which leads to rapid production of other inflammatory cytokines (Suzuki et al., 2000). Evidences have indicated that TNF- $\alpha$ plays a vital role in the progression of multiple organ failure in endotoxic shock (Damas et al., 1989; Song et al., 2009). IL-6 is another important pro-inflammatory cytokine and elevated levels initiate the oxidative burst and lead to production of toxic metabolites and lysosomal 
enzymes responsible for tissue damage (Kishimote et al., 1992; Remick et al., 2002). Drug that can inhibit TNF- $\alpha$ and IL- 6 expression has beneficial effect in the treatment of endotoxic shock (Haveman et al., 1999). Our study confirmed that pretreatment with cavidine reduced concentration of TNF- $\alpha$ and IL-6 in serum and tissue following LPS injection.

It has been documented that LPS, TNF- $\alpha$ or IL- 6 can stimulate the production of HMGB1 by monocytes (Yang et al., 2004). We measured the levels of HMGB1 in LPS-induced mice and macrophage. Results showed that LPS stimulation elevated HMGB1 levels, however pretreatment with cavidine suppressed the expression of HMGB1 both in LPS-induced mice and macrophage. HMGB1 protein is an important late-phase mediator in the pathogenesis of endotoxic shock (Wang et al., 1999). There is a reciprocal functional relationship between the activities of the early (TNF- $\alpha$ and IL-6) and late (HMGB1) cytokines, which apparently mean that HMGB1 participates in the "cross-talk" for the propagation and amplification of downstream pro-inflammatory responses (Andersson et al., 2000). Current literature indicates that HMGB1 plays an important role in mediating tissue injury and damage applies to both acute and chronic diseases (Andersson and Tracey, 2011). Targeting HMGB1 with antibodies or specific antagonists is beneficial in many preclinical inflammatory diseases including endotoxemia or sepsis, collagen-induced arthritis (Yang and Tracey, 2010) .

HMGB1 activates a cascade of inflammatory responses that can cause tissue 
damage and even death. To elucidate inhibitory mechanism of cavidine on HMGB1 expression, we investigated the effect of cavidine on the activation of ERK-1/2 and p38 in tissue of lung, liver and kidney from endotoxic shock mice. Results showed that phosphorylation of ERK-1/2 and p38 was markedly induced by stimulation with LPS, whereas treatment with cavidine significantly inhibited theirs expression. Inhibition of SB203580 (p38 MAPK inhibitor) and PD98059 (ERK1/2 inhibitor) on HMGB1 expression in LPS-activated macrophages was also evaluated. Results showed that pretreatment with the specific p38 MAPK inhibitor SB203580 or ERK1/2 inhibitor PD98059 had an inhibition on the production of HMGB1, which suggested the release of HMGB1 was related to activation p38 and ERK-1/2 MAPK pathways. We also investigated the regulation of cavidine on production of HMGB1 and phosphorylation of p38, ERK-1/2 MAPK. Data demonstrated that cavidine significantly inhibited expression of HMGB1 and activation of p38 MAPK and ERK1/2 in LPS-induced macrophages. These results demonstrated that cavidine treatment inhibited LPS-induced HMGB1 production through blocking activation of p38 MAPK and ERK-1/2. It has been reported that MAPK family is implicated as a critical mediator of signal transduction pathways that appear to play an important role in inflammatory responses. Once activated by kinases, MAPK can phosphorylate transcription factors or other downstream kinases that produce pro-inflammatory mediators of extracellular stimuli (Garrington and Johnson, 1999). Our study confirmed that cavidine inhibited LPS-induced HMGB1 production via regulating MAPK signal pathway. 
Previous study found, there were few reports about the effects of cavidine on endotoxin-induced shock in mice, especially within $24 \mathrm{~h}$ after an endotoxin injection. Present study clearly demonstrates that pretreatment with cavidine reduces the mortality of mice during $72 \mathrm{~h}$ after endotoxin injection. In addition, cavidine administration significantly attenuates histological pathophysiology features of LPS-induced injury in lung, liver and kidney. And also that in the presence of cavidine, there is an inhibitory effect on endotoxin-induced production of pro-inflammatory cytokines in serum and tissues such as TNF- $\alpha$, IL-6 and HMGB1. Furthermore cavidine's effects on HMGB1 may be related to p38 MAPK and ERK1/2 pathway. In summary, results of this study suggest that cavidine has potent protective effect on mice during whole endotoxic shock stage.

\section{Conflict of Interest}

The authors have declared that there is no conflict of interest.

\section{Acknowledgements}

This research was financially supported by Shaanxi National Science Foundation of international cooperation projects (No. 2013KW26-02) to W.F Li. 


\section{References}

Alves, J.N., Pires, K.M.P., Lanzetti, M., Barroso, M.V., Benjamim, C.F., Costa, C.A., Valença, S.S., 2013. Critical role for CCR2 and HMGB1 in induction of experimental endotoxic shock. Arch. Biochem. Biophys. 537, 72-81.

Andersson, U., and Tracey, K.J., 2011. HMGB1 is a therapeutic target for sterile inflammation and infection. Annu. Rev. Immuno. 29, 139-162.

Andersson, U., Wang, H., Palmblad, K., Aveberger, A.C., Bloom, O., Erlandsson-Harris, H., Tracey, K.J., 2000. High mobility group 1 protein (HMG-1). stimulates proinflammatory cytokine synthesis in human monocytes. J. Exp. Med. 192, 565-570.

Czura, C.J., and Tracey, K.J., 2003. Targeting high mobility group box 1 as a late-acting mediator of inflammation. Crit. Care. Med. 31, S46-50.

Damas, P., Reuter, A., Gysen, P., Demonty, J., Lamy, M., Franchimont, P., 1989. Tumor necrosis factor and interleukin-1 serum levels during severe sepsis in humans.Crit. Care. Med. 17,975-978.

Dinarello, C.A., 1997. Proinflammatory and anti-inflammatory cytokines as mediators in the pathogenesis of septic shock. Chest. 112, 321-329.

Dinarello, C. A., 2000. Proinflammatory cytokines. Chest. 118, 503-508.

Feng, Y., Yang, Q., Xu, J., Qian, G., Liu, Y. 2008. Effects of HMGB1 on PMN apoptosis during LPS-induced acute lung injury. Exp. Mol. Pathol. 85, 214-222.

Freudenberg, M., and Galanos C., 1990. Bacterial lipopolysaccharides: structure, metabolism and mechanisms of action. Int. Rev. Immunol. 6, 207-221.

Garrington, T.P., and Johnson, G.L., 1999. Organization and regulation of mitogen-activated protein kinase signaling pathways. Curr. Opin. Cell. Biol. 11, 211-218.

Haveman, J.W., Kobold, A.M., Tervaert, J.C., Van den Berg, A.P., Tulleken, J.E., Kallenberg, G.M., The, T.H., 1999. The central role of monocytes in the pathogenesis of sepsis: consequences for immunomonitoring and treatment. Neth. J. Med. 55, 132-141.

Hsu, B.G., Lee, R.P., Yang, F.L., Harn, H.J., Chen, H.I., 2006. Post-treatment with 
$\mathrm{N}$-acetylcysteine ameliorates endotoxin shock-induced organ damage in conscious rats. Life. Sci. 79, 2010-2016.

Johnson, G.L., Dohlman, H.G., Graves, L.M., 2005. MAPK kinase kinases (MKKKs) as a target class for small-molecule inhibition to modulate signaling networks and gene expression. Curr. Opin. Chem. Biol. 9, 325-331.

Kishimote, T., Akira, S., Taga, T., 1992. Interleukln-6 and Its Receptor: a paradigm for cytoklnes. Science. 258, 593-597.

Kuhns, D.B., Alvord, W.G., Gallin, J.I., 1995. Increased circulating cytokines, cytokine antagonists, and E-selectin after intravenous administration of endotoxin in humans. J. Infect. Dis. 171,145-152.

Kumar, V., Sharma A., 2010. Is neuroimmunomodulation a future therapeutic approach for sepsis? Int. Immunopharmacol. 10, 9-17.

Li, S., Bao, H., Han, L., Liu, L. 2010. Effects of propofol on early and late cytokines in lipopolysaccharide-induced septic shock in rats. J. Biomed. Mate. Res. 24, 389-394.

Li, W.F., Li, H.N., Mu, Q.L., Zhang, H.L., Yao, H., Li, J.S., Niu, X.F., 2014. Protective effect of sanguinarine on LPS-induced endotoxic shock in mice and its effect on LPS-induced COX-2 expression and COX-2 associated PGE 2 release from peritoneal macrophages. Int. Immunopharmacol. 22, 311-317.

Liu, L., Mu, Q.L., Li, W.F., Xing, W., Zhang, H.L., Fan, T., He, L.C., 2015. Isofraxidin protects mice from LPS challenge by inhibiting pro-inflammatory cytokines and alleviating histopathological changes. Immunobiology. 220, 406-413.

Liu, Z.W., Fan, Y.M., Wang, Y., Han, C., Pan, Y., Huang, H., Yin, Z.M., 2008. Dipyrithione inhibits lipopolysaccharide-induced iNOS and COX-2 up-regulation in macrophages and protects against endotoxic shock in mice. FEBS. lett. 582, 1643-1650.

Nduka, O.O, and Parrillo, J.E., 2009. The pathophysiology of septic shock. Crit. Care. Clin. 25, 677-702.

Niu, X.F., Xu, H.B., Liu, X., Fan, T., Qi, L. 2013. Isoquinoline alkaloids from 21 
Corydalis impatiens. Chem. Nat. Compd. 49, 187-189.

Niu, X.F., Zhang, H.L., Li, W.F., Mu, Q.L., Yao, H., Wang, Y. 2015. Anti-inflammatory Effects of Cavidine In Vitro and In Vivo, a Selective COX-2 Inhibitor in LPS-Induced Peritoneal Macrophages of Mouse. Inflammation. 38, 923-933.

Qi, Z., Yin, F., Lu, L., Shen, L., Qi, S., Lan, L., Yin, Z.., 2013. Baicalein reduces lipopolysaccharide-induced inflammation via suppressing JAK/STATs activation and ROS production. Inflamm. Res. 62, 845-855.

Remick, D.G., Bolgos, G.R., Siddiqui, J., Shin, J., Nemzek, J.A., 2002. Six at six: interleukin- 6 measured $6 \mathrm{~h}$ after the initiation of sepsis predicts mortality over 3 days. Shock. 17, 463-467.

Roux, P.P., and Blenis, J., 2004. ERK and p38 MAPK-activated protein kinases: a family of protein kinases with diverse biological functions. Microbiol. Mol. Boil. Re. 68, 320-344.

Song, X. M., Wang, Y.L., Li, J.G., Wang, C.Y., Zhou, Q., Zhang, Z.Z., Liang, H., 2009. Effects of propofol on pro-inflammatory cytokines and nuclear factor kappaB during polymicrobial sepsis in rats. Mol. Boil. Rep. 36, 2345-2351.

Stearns-Kurosawa, D.J., Osuchowski, M.F., Valentine, C., Kurosawa, S., Remick, D.G., 2011. The pathogenesis of sepsis. Annu. Rev. Pathol. 6, 19.

Sun, N., and Chao, C., 2005. The cytokine activity of HMGB1-extracellular escape of the nuclear protein. Chang Gung medical journal. 28, 673.

Suzuki, K., Tateda, K., Matsumoto, T., Gondaira, F., Tsujimoto, S., Yamaguchi, K. 2000. Effects of interaction between Escherichia coli verotoxin and lipopolysaccharide on cytokine induction and lethality in mice. J. Med. Microbial. 49, 905-910.

Szarka, R.J., Wang, N., Gordon, L., Nation, P.N., Smith, R.H., 1997. A murine model of pulmonary damage induced by lipopolysaccharide via intranasal instillation. J. Immunol. Methods. 202, 49-57.

Takano, H., Yoshikawa, T., Yamaguchi, T., Hongo, H., Fujii, T., Boku, Y., Kondo, M., 1997. Effects of aminoguanidine on systemic inflammatory response 
syndrome induced by platelet activating factor and by lipopolysaccharide in rats. Eur. J. Pharmacol. 323, 107-110.

Wang, H., Bloom, O., Zhang, M., Vishnubhakat, J.M., Ombrellino, M., Che, J., Tracey, K. J. 1999. HMG-1 as a late mediator of endotoxin lethality in mice. Science. $285,248-251$.

Yang, H., Ochani, M., Li, J., Qiang, X., Tanovic, M., Harris, H.E., Tracey, K.J., 2004. Reversing established sepsis with antagonists of endogenous high-mobility group box 1. P. Natl. Acad. Sci. 101, 296-301.

Yang, H., and Tracey, K.J., 2010. Targeting HMGB1 in inflammation. BBA-Gene. Regu. Mech. 1799, 149-156. 


\section{Figure legends}

Fig.1. Structure of cavidine

Fig.2. Effects of different doses of cavidine on survival rate of LPS-induced endotoxic shock mice. Data are expressed as the means $\pm \mathrm{SE}(\mathrm{n}=6) .{ }^{\# \#} P<0.01$ compared with the control group, $* P<0.05$ compared with the LPS group

Fig.3 Effect of cavidine on serum TNF- $\alpha$ (A), IL-6 (B), and HMGB1 (C) after LPS injection. The serous level of TNF- $\alpha$, IL-6 and HMGB1 were measured using ELISA. Three independent experiments were performed and data are expressed as the means $\pm \mathrm{SE}(\mathrm{n}=6) .{ }^{\# \#} P<0.01$ compared with the control group; $* * P<0.01$ compared with the LPS group.

Fig.4 Effect of cavidine on the protein expression of TNF- $\alpha$ (A), IL-6 (B), and HMGB1 (C) in lung, liver and kidney tissue. The serous level of TNF- $\alpha$, IL-6 and HMGB1 were measured using ELISA. Data are expressed as the means \pm SE $(n=6)$. ${ }^{\# \#} P<0.01$ compared with the control group; ${ }^{*} P<0.05$ and ${ }^{*} * P<0.01$ compared with the LPS group.

Fig.5. Effects of cavidine on the microscopic appearances in mouse lung with LPS-induced. (A) Normal control group; (B) LPS group; (C) LPS + $1 \mathrm{mg} / \mathrm{kg}$ cavidine; (D) LPS + $3 \mathrm{mg} / \mathrm{kg}$ cavidine; (E) LPS + $10 \mathrm{mg} / \mathrm{kg}$ cavidine; (F) LPS + $5 \mathrm{mg} / \mathrm{kg}$ DEX. 
Histopathological sections were stained by H.E. Original magnification $100 \times$. The injury score was represented in the right of the image. Data are expressed as the means $\pm \mathrm{SE}(\mathrm{n}=6) .{ }^{\# \#} P<0.01$ compared with the control group; $* * P<0.01$ when compared with the LPS group.

Fig.6 Effect of cavidine on the microscopic appearances of liver in mice with LPS-induced (H\&E staining, magnification $\times 100)$. (A) Normal control group; (B) LPS group; (C) LPS + $1 \mathrm{mg} / \mathrm{kg}$ cavidine; (D) LPS + $3 \mathrm{mg} / \mathrm{kg}$ cavidine; (E) LPS + 10 $\mathrm{mg} / \mathrm{kg}$ cavidine; (F) LPS $+5 \mathrm{mg} / \mathrm{kg}$ DEX. The injury score was represented in the right of the image. Data are expressed as the means $\pm \mathrm{SE}(\mathrm{n}=6) .{ }^{\#} P<0.01$ compared with the control group; ${ }^{* *} P<0.01$ compared with the LPS group.

Fig.7 Effect of cavidine on the microscopic appearances in mice kidney with LPS-induced $(H \& E$ staining, magnification $\times 100)$. (A) Normal control group; (B) LPS group; (C) LPS + $1 \mathrm{mg} / \mathrm{kg}$ cavidine; (D) LPS $+3 \mathrm{mg} / \mathrm{kg}$ cavidine; (E) LPS + 10 $\mathrm{mg} / \mathrm{kg}$ cavidine; (F) LPS $+5 \mathrm{mg} / \mathrm{kg}$ DEX. The injury score was represented in the right of the image. Data are expressed as the means $\pm \mathrm{SE}(\mathrm{n}=6) .{ }^{\#} P<0.01$ compared with the control group; $* * P<0.01$ compared with the LPS group.

Fig.8 Immunohistochemical analysis for HMGB1 expression in lung, liver and kidney tissue after LPS injection. (A) Normal control group; (B) LPS group; (C) LPS + 1 $\mathrm{mg} / \mathrm{kg}$ cavidine; (D) LPS $+3 \mathrm{mg} / \mathrm{kg}$ cavidine; (E) LPS + $10 \mathrm{mg} / \mathrm{kg}$ cavidine; (F) LPS 
$+5 \mathrm{mg} / \mathrm{kg}$ DEX. The density of HMGB1 was represented in the below of the image. Original magnification 100x. Data are expressed as the means $\pm \operatorname{SE}(\mathrm{n}=6) .{ }^{\# \#} P<0.01$ compared with the control group; $* * P<0.01$ compared with the LPS group.

Fig.9 Effect of cavidine on the protein expression of on HMGB1 in mice lung, liver and kidney tissue. The HMGB1proteins were assessed by Western blotting. Data are expressed as protein levels of HMGB1 corrected to GAPDH, the loading control. Data are expressed as the means $\pm \mathrm{SE}(\mathrm{n}=6) .{ }^{\# \#} P<0.01$ compared with the control group; $* * P<0.01$ compared with the LPS group.

Fig.10 Effect of cavidine on the protein expression of on MAPK signal pathway in lung, liver and kidney tissue. The p38 and ERK 1/2 proteins were assessed by Western blotting. Data are expressed as protein levels of p38 and ERK 1/2 corrected to GAPDH, the loading control. Data are expressed as the means $\pm \mathrm{SE}(\mathrm{n}=6) .{ }^{\# \#} P<$ 0.01 compared with the control group; $* P<0.05$ and $* * P<0.01$ compared with the LPS group.

Fig.11 Effect of cavidine on expression of HMGB1 in peritoneal macrophages with LPS induced. The level of HMGB1 was analyze by ELISA. Three independent experiments were performed and data are expressed as the means $\pm \mathrm{SE}(\mathrm{n}=6) .{ }^{\# \#} P<$ 0.001 compared with the control group; $* * P<0.01$ compared with the LPS group. 
Fig.12 Effect of cavidine on the protein expression of HMGB1 and MAPK signal pathway in peritoneal macrophages with LPS induced. (A) The proteins were extracted and assessed for HMGB1, p38 and ERK1/2 by western blot. (B) Protein levels of HMGB1, p38 and ERK1/2 corrected to GAPDH, the loading control. Data are expressed as the means $\pm \mathrm{SE}(\mathrm{n}=6) .{ }^{\# \#} P<0.01$ compared with the control group; $* * P<0.01$ compared with the LPS group. 


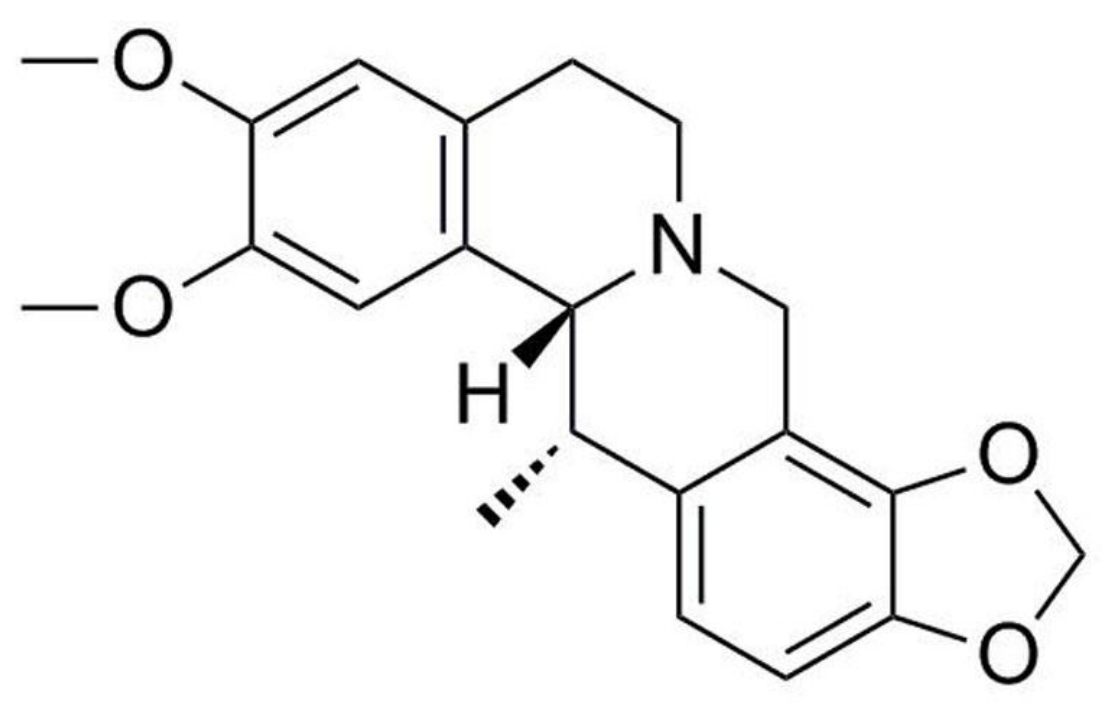




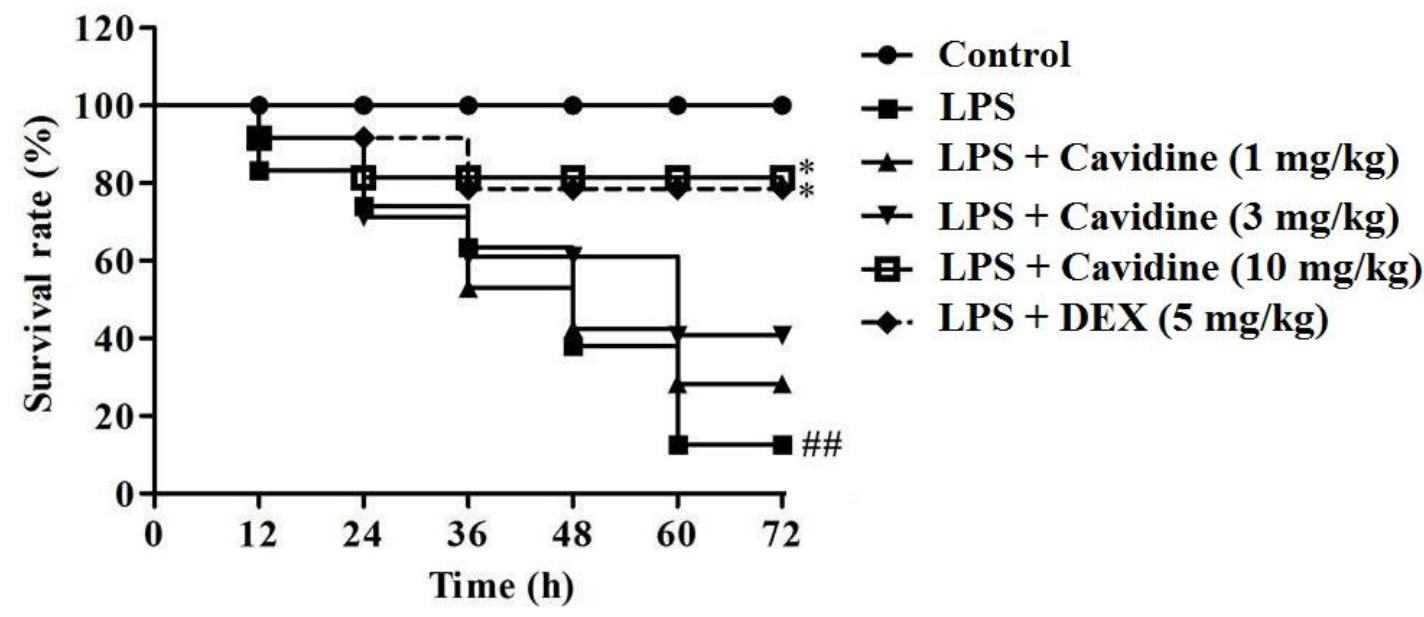



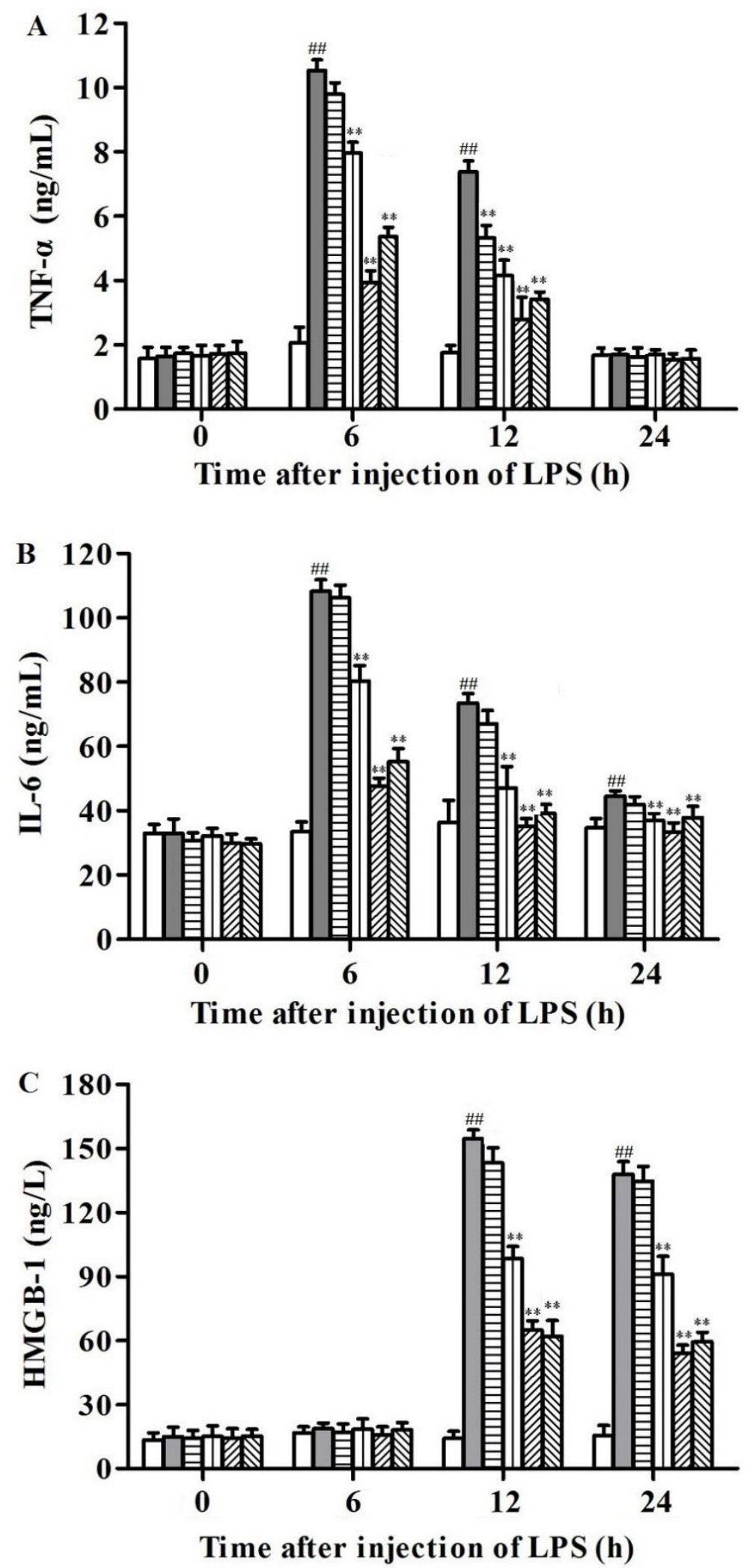
$\square$ Control
LPS + Cavidine (1 mg/kg)
$\square$ LPS
UII LPS + Cavidine (3 mg/kg)
LPS + DEX $(5 \mathrm{mg} / \mathrm{kg})$
IIA LPS + Cavidine (10 $\mathrm{mg} / \mathrm{kg})$ 

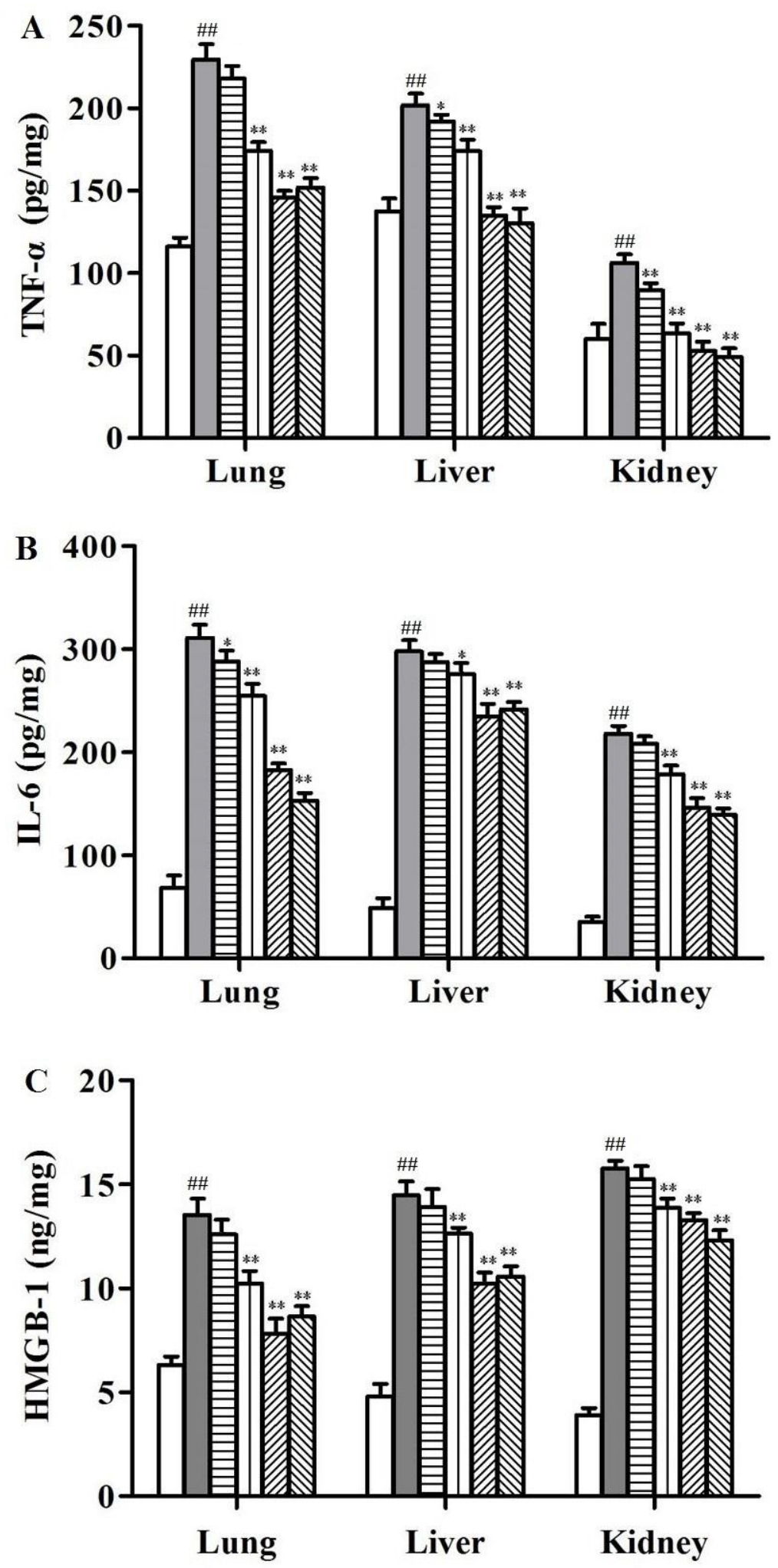

$\square$ Control

$\square$ LPS

LPS + DEX $(5 \mathrm{mg} / \mathrm{kg})$
E LPS + Cavidine $(1 \mathrm{mg} / \mathrm{kg})$

LII + Cavidine (3 mg/kg)

IIA LPS + Cavidine $(10 \mathrm{mg} / \mathrm{kg})$ 

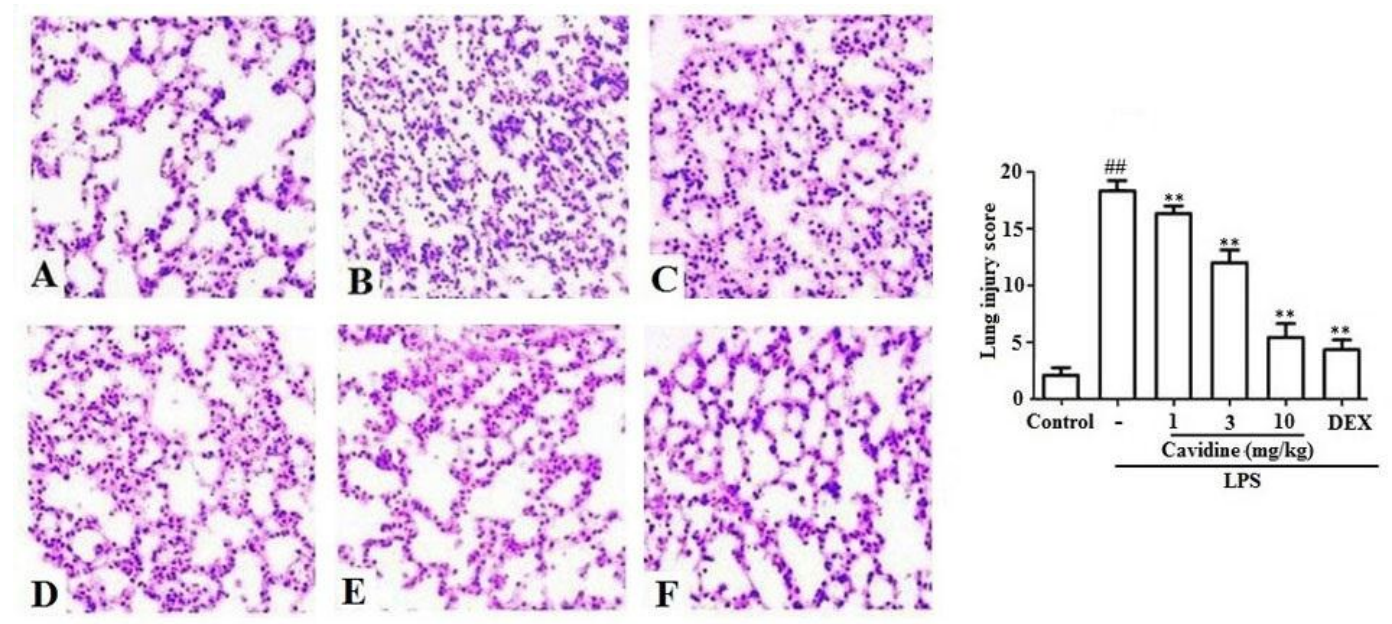


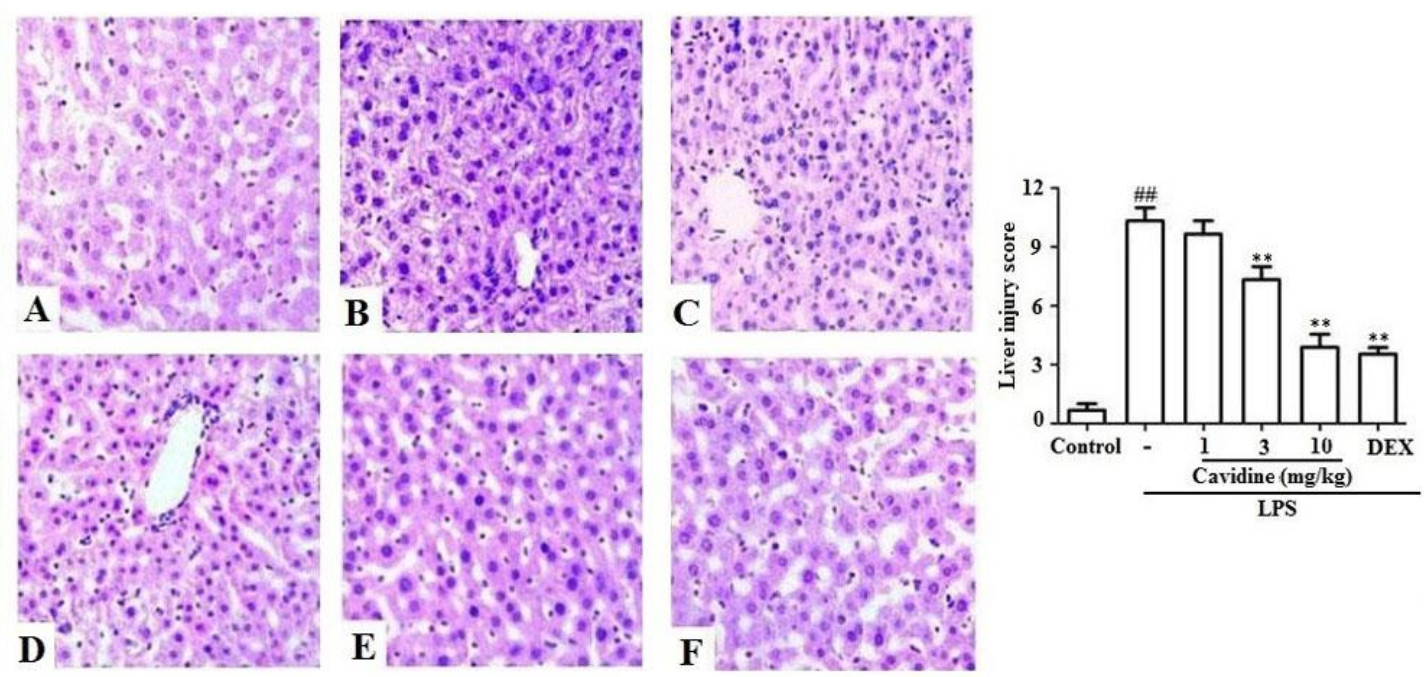



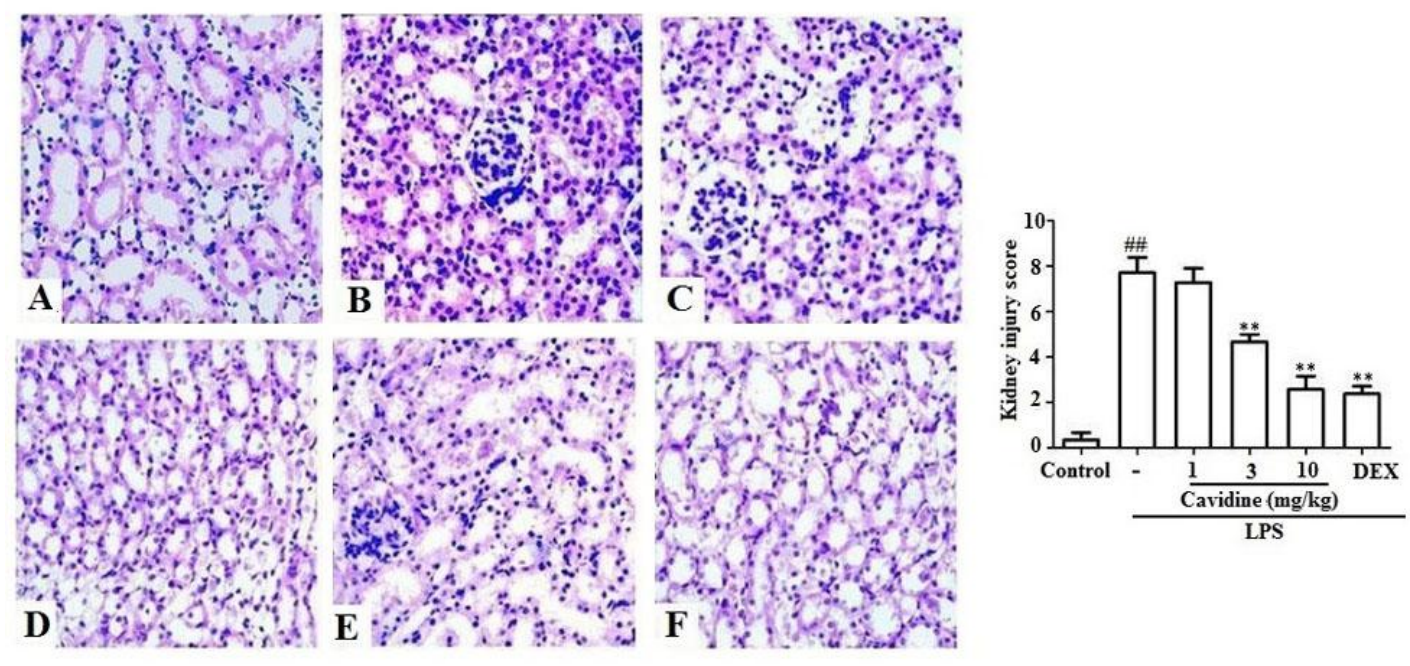


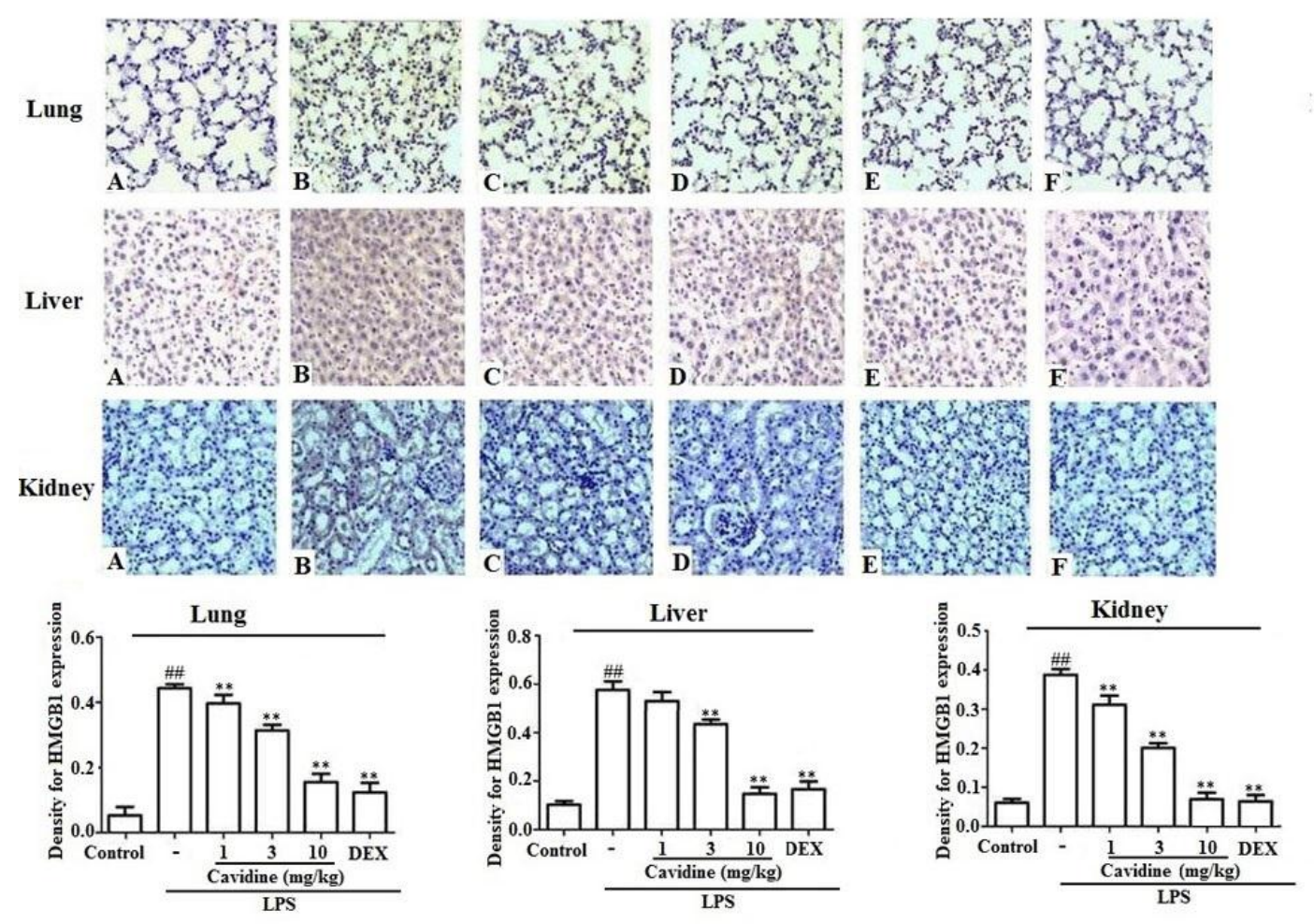



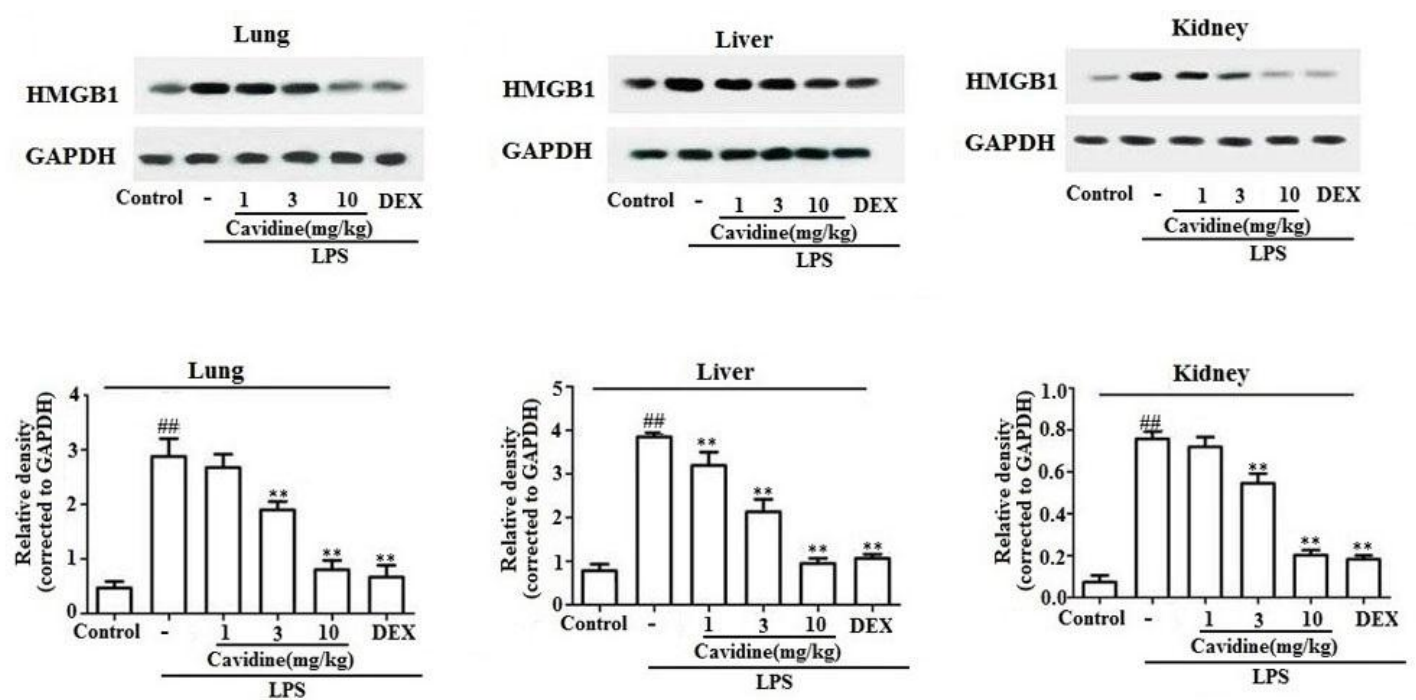
Lung

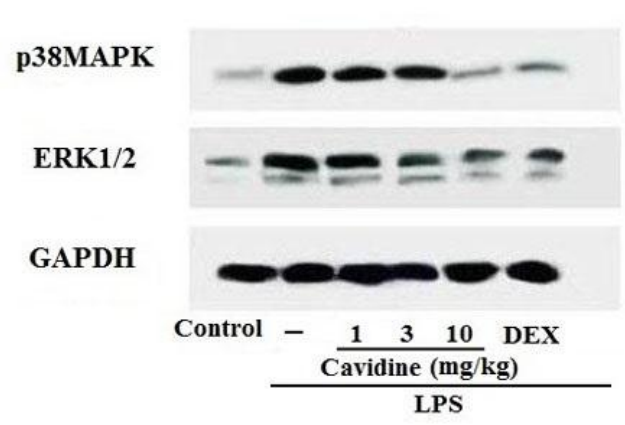

Liver

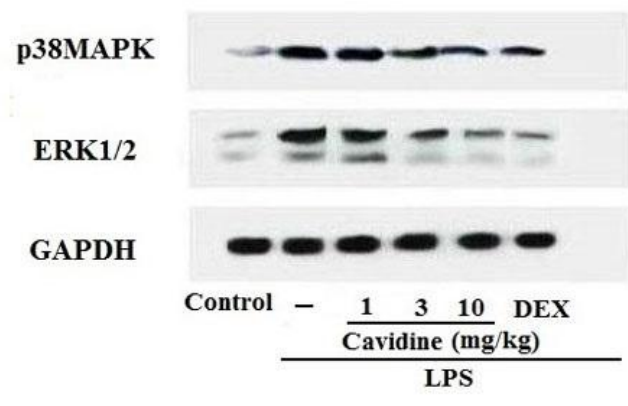

Kidney

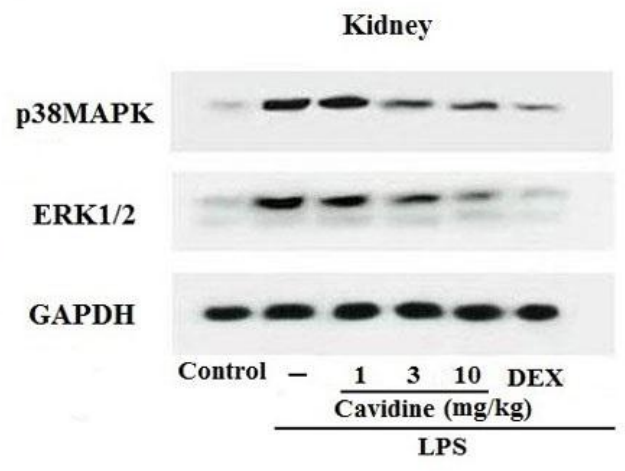

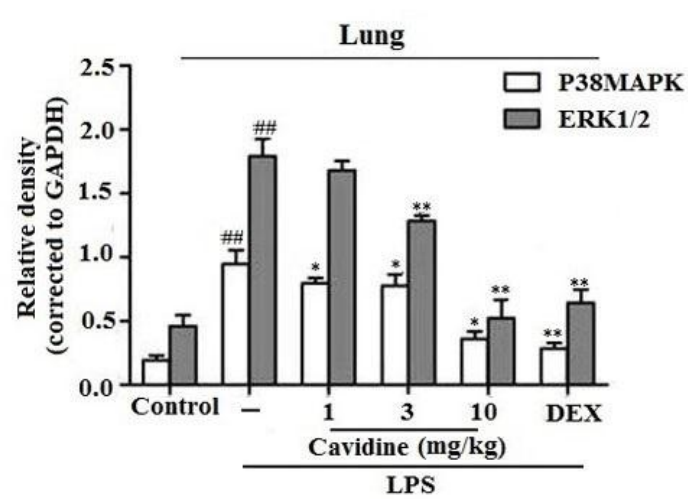
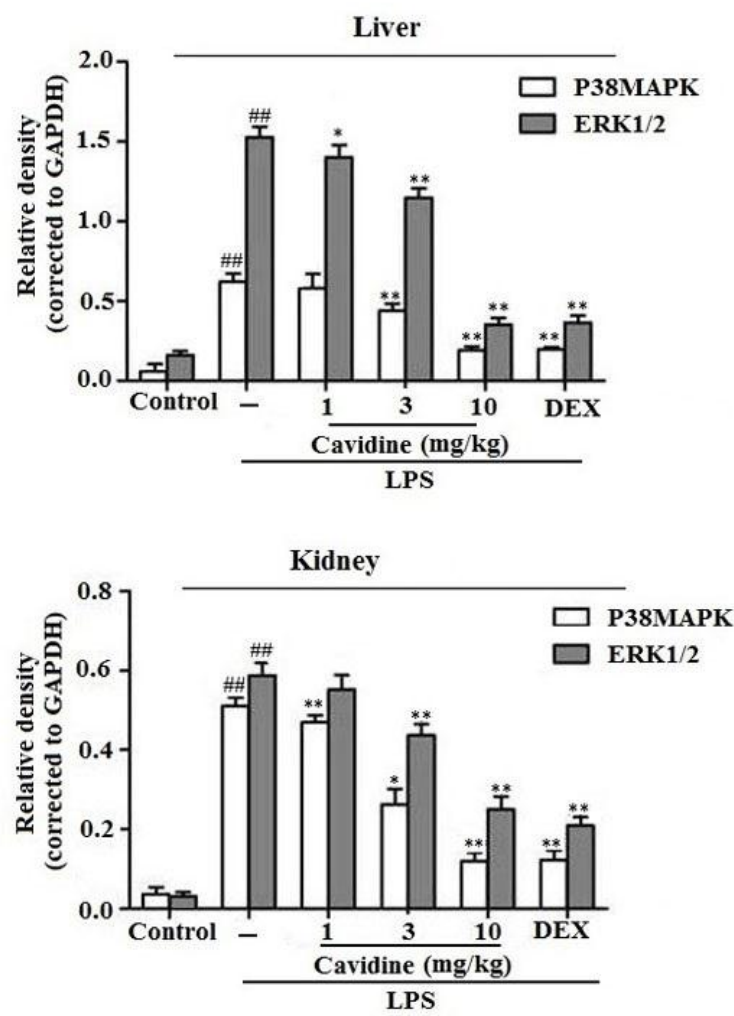


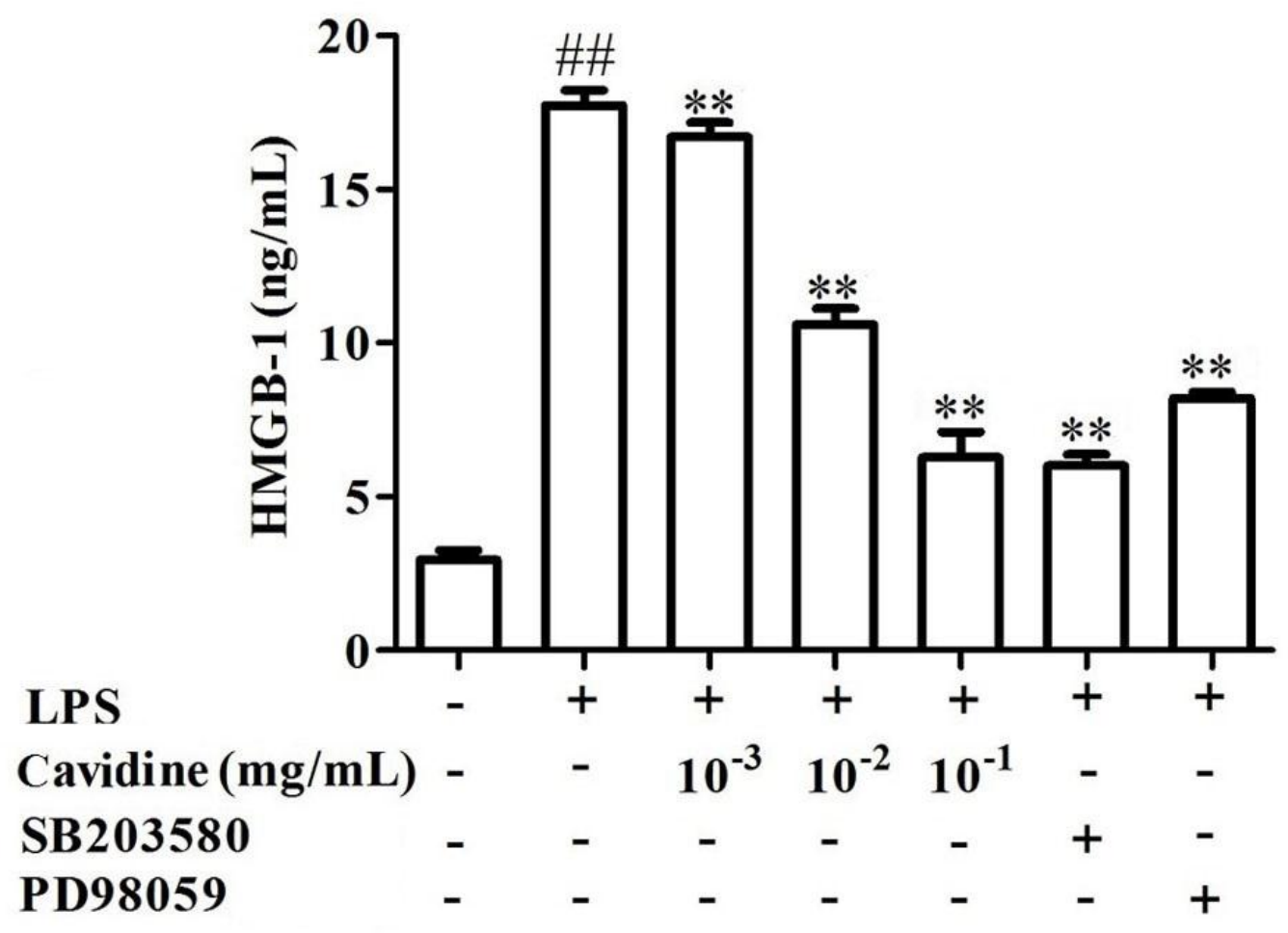


A

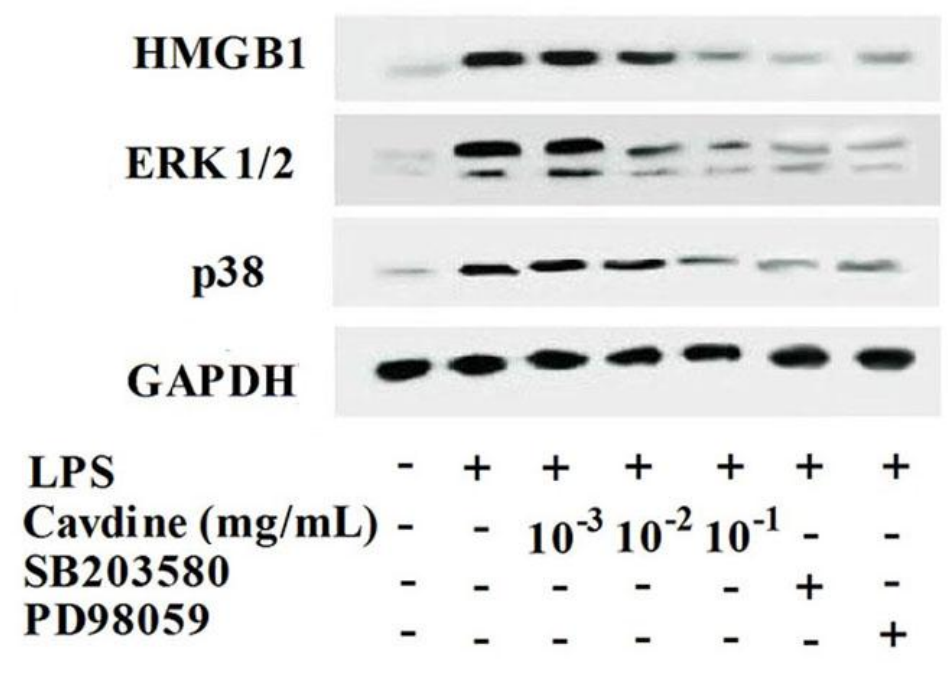

B

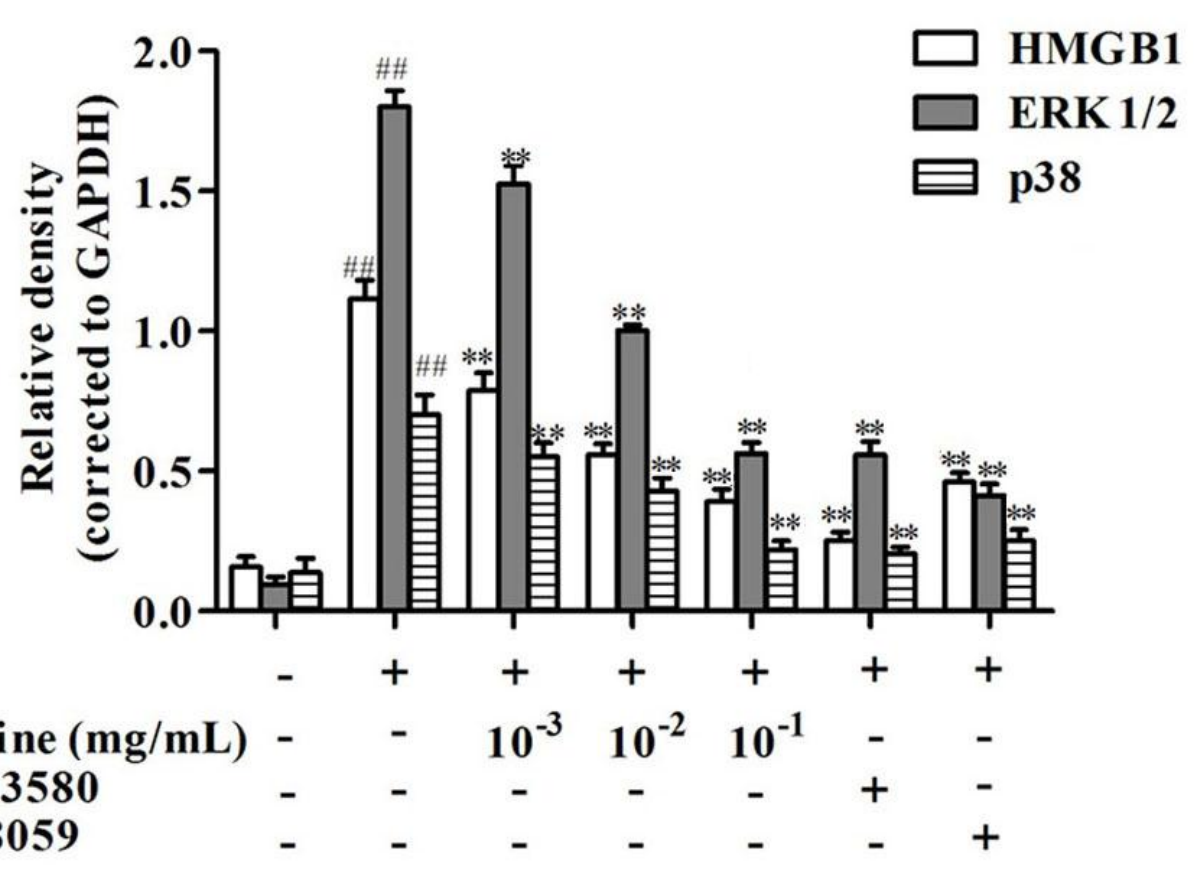


Cavidine administration

LPS injection

LPS-induced

endotoxic shock mice
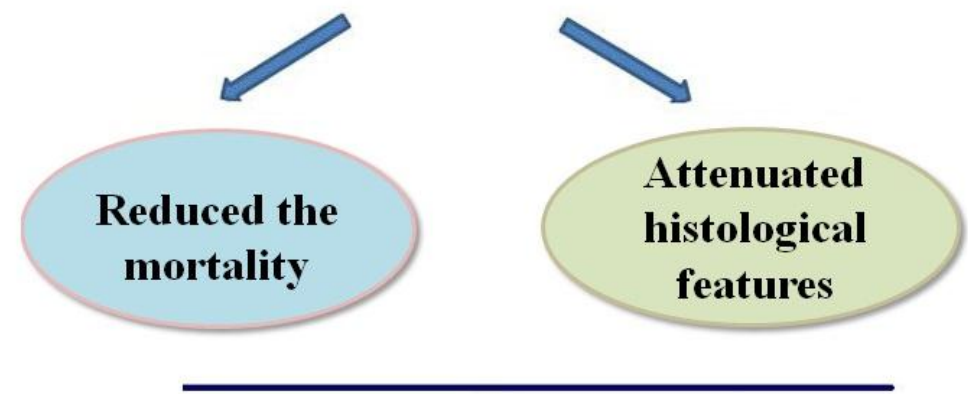

Mechanism exploration
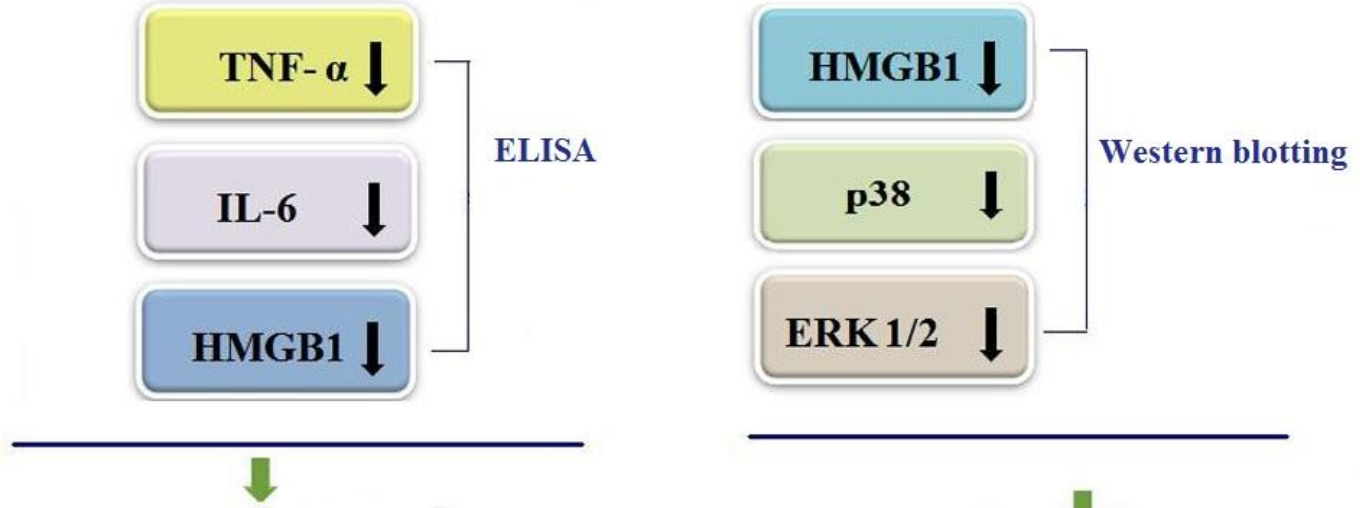

Cavidine protects mice against LPS-induced endotoxic shock 